Journal of

Molecular Microbiology and Biotechnology

Alegre, E.R. 291

Barabote, R.D. 345

Bibi, E. 308

Cohen-Karni, D. 308

Jakobsson, E. 326

Kelley, S.T. 291
Lolkema, J.S. 318

McMahon, A.M. 326

Nguyen, T.X. 291, 345

Pacold, M.E. 326

Ren, Q. 289

Saier, Jr., M.H. 289, 302, 345
Siemion, S. 308

Sigal, N. 308

Soberón, X. 302

Tseng, T.-T. 326

Yen, M.-R. 345

Zahm, R.J. 326

\title{
Subject Index Vol. 11, No. 6, 2006
}

Auxiliary subunits 326

Bacteria 302

Bacterial phosphotransferase system 345

Bioengineering 302

Bioinformatic analyses 345

Bioinformatics 291

Calcium channels 326

Directed evolution 302

Domain structure 318

Integral membrane proteins 345

MdfA, E. coli 308

-, mechanism of multidrug transport 308
-, putative multidrug recognition pocket 308

-, structural features 308

-, substrate binding 308

Membrane protein 318

- topology 318

- transport 326

MemGen 318

Model systems 302

Molecular genetics 302

ompC 291

ompF 291

Outer membrane protein 291
Phosphotransferase system 302

Phylogeny 291, 326, 345

Pore loop 318

Porin 291

PTS permease 345

Secondary multidrug transporters 308

- transport 318

Structural classification 318

Topology 345

Transporter classification 326 